\title{
Comparative susceptibility of veliger larvae of four bivalve mollusks to a Vibrio alginolyticus strain
}

\author{
A. Luna-González, A. N. Maeda-Martínez* , J. C. Sainz, F. Ascencio-Valle \\ Centro de Investigaciones Biológicas del Noroeste S.C. (CIBNOR), PO Box 128, La Paz, Baja California Sur 23000, Mexico
}

\begin{abstract}
The susceptibility of $7 \mathrm{~d}$ old veliger larvae of the scallops Argopecten ventricosus and Nodipecten subnodosus, the penshell Atrina maura, and the Pacific oyster Crassostrea gigas to a pathogenic strain of Vibrio alginolyticus was investigated by challenging the larvae with different bacterial concentrations in a semi-static assay. The results indicate that the larvae of the 2 scallop species are more susceptible to the $V$. alginolyticus strain than those of the oyster and the penshell. Signs of the disease were similar to bacillary necrosis described in previous work. Interspecies differences in susceptibility to pathogens are discussed.
\end{abstract}

KEY WORDS: Vibrio alginolyticus · Pathogenicity · Vibriosis · Mollusks · Scallops · Pacific oyster · Penshell

\section{INTRODUCTION}

Most of the current scallop aquaculture industry relies on wild spat collected from selected sites, although this method shows wide variations in yields over time. Hatchery production, as an alternative method, does not provide a reliable source of spat for the industry because of the high susceptibility of the larvae to pathogenic bacteria. Susceptibility of cultured scallop larvae to Vibrio bacteria has been demonstrated in several scallop species such as Argopecten ventricosus (Sainz et al. 1999), Euvola (Pecten) ziczac (Freites et al. 1993), Argopecten purpuratus (Riquelme et al. 1995), Aequipecten irradians (Tubiash et al. 1965), and Pecten maximus (Nicolas et al. 1992,1996). P. maximus spat production requires prophylactic addition of chloramphenicol to larval cultures at 2 French hatcheries to eliminate gradual or sudden larval mortality (Nicholas et al. 1996). While oyster hatcheries are not immune to Vibrio outbreaks (Brown 1973, DiSalvo et al. 1978, Elston \& Leibovitz 1980, Garland et al. 1983), the huge Pacific oyster aquaculture industry of Crassostrea

*Corresponding author. E-mail: amaeda@cibnor.mx gigas, which is now practiced around the world, has relied (with the exception of Japan) for a long time on hatchery spat. This suggests that larvae of certain groups of mollusks may have stronger innate internal defenses than others, or perhaps there are differences in the maturation rate of the immune system during early development. This is supported by the results of a susceptibility study by Tubiash et al. (1965), who found that larvae of $A$. irradians were more susceptible to a Vibrio strain than 3 other lamellibranch species (Mercenaria mercenaria, Crassostrea virginica, and Ostrea edulis) and 1 shipworm (Teredo navalis) species. Nicolas et al. $(1992,1996)$ suggested that differences in susceptibility could not result from inherited resistance, but were due to the occurrence of highlypathogenic species-specific bacteria. Strains isolated from dead scallop larvae were highly virulent to the scallop but not to oyster larvae, and vice versa. A Vibrio strain was only pathogenic to Manila clam (Tapes philippinarum) larvae and postlarvae, but not to oyster (C. gigas) and scallop (P. maximus) larvae (Nicolas et al. 1992). Very little is known about immune reactions in early stages of invertebrate life cycles (see review of Dyrynda et al. 1995). However, some elements (degradative enzymes, phagocytosis, and reactive oxygen 


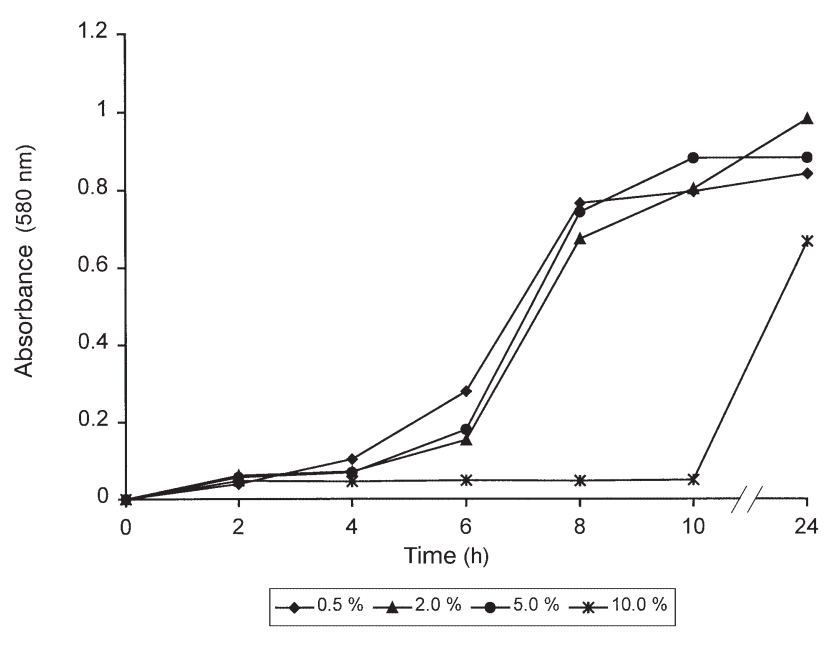

Fig. 1. Vibrio alginolyticus APSA2. Growth of bacteria cultured in trypicase soy broth at $28^{\circ} \mathrm{C}$ and at different $\mathrm{NaCl}$ concentrations

metabolites) of the immune system in adult Mytilus edulis are also present in the trochophore and veliger larvae of this species (see review of Dyrynda et al. 1995). Recently, Mitta et al. (2000) found that synthesis of the antimicrobial peptide mytilina occurs during metamorphosis of larvae of Mytilus galloprovincialis, and the antimicrobial peptide defensin is detected when metamorphosis is finished.

In the present paper, veliger larvae of 4 bivalves, comprising 2 scallops (Argopecten ventricosus and Nodipecten subnodosus), a penshell (Atrina maura) and the Pacific oyster (Crassostrea gigas) were challenged with different concentrations of Vibrio alginolyticus selected from several strains of the same and other species ( $V$. tubiashii, V. parahaemolyticus, $V$. vulnificus and $V$. campbelli) tested in $24 \mathrm{~h}$ bioassays on veliger larvae of $A$. ventricosus. $V$. alginolyticus was isolated during bacterial screening in a shrimp hatchery.

\section{MATERIALS AND METHODS}

Bacteriology. A Vibrio alginolyticus strain named APSA2 was isolated from a hatchery of white shrimp (Farfantepenaeus vannamei) postlarvae, in La Paz, Baja California Sur, Mexico, during bacterial screening. The isolate was identified as $V$. alginolyticus by Dr. John McInroy at Auburn University, Alabama, USA. The strain was kept in Luria-Bertani medium (LBM) containing $3 \% \mathrm{NaCl}$ and stored at $4^{\circ} \mathrm{C}$ until needed. For the susceptibility assays, liquid bacterial cultures were prepared in trypticase soy broth (TSB) (Difco). To find the optimum salinity for bacterial growth, a preliminary assay was run by inoculating the strain into TSB media containing 0.5, 2.0, 5.0, and $10.0 \% \mathrm{NaCl}$. Cultures were incubated at $28^{\circ} \mathrm{C}$, and growth was estimated by reading absorbance of the cultures in a Spectronic Genesys 2 spectrophotometer at $580 \mathrm{~nm}$, and at $0,2,4,8,10$, and $24 \mathrm{~h}$ from inoculation. With these results (Fig. 1), bacterial cultures were subsequently prepared in $2 \% \mathrm{NaCl}$ TSB.

Bivalve larvae. Adult Argopecten ventricosus, Nodipecten subnodosus, Atrina maura, and Crassostrea gigas, were brought to the hatchery at Centro de Investigaciones Biologicas del Noroeste, La Paz, and were conditioned for spawning for at least $15 \mathrm{~d}$ in $1100 \mathrm{l}$ fiberglass tanks containing sea water at $25^{\circ} \mathrm{C}$ and $36 \%$. Broodstock were fed with $1.5 \times 10^{5}$ cells ml $^{-1}$ of an algal mixture of Chaetoceros calcitrans, Isochrysis galbana, and C. gracilis (1:1:2). Half of the water was changed daily. After the conditioning period, the bivalves were induced to spawn by thermal shock (one species at a time) and the resulting larvae were cultured in $5000 \mathrm{l}$ conical tanks with filtered $(3 \mu \mathrm{m})$ sea water at $25^{\circ} \mathrm{C}, 36 \%$. The larvae were fed with $3.0 \times 10^{5}$ cells $\mathrm{ml}^{-1}$ of $I$. galbana and C. calcitrans (1:1). On Day 6, the largest larvae were selected and removed with a plankton net, washed with filtered sea water, and resuspended in $20 \mathrm{ml}$ sterile sea water at the same temperature and salinity as the cultures. The larvae contained in a $0.1 \mathrm{ml}$ sample in a petri dish containing a drop of $10 \%$ formalin were counted under a stereomicroscope; 200 larvae were transferred to $150 \mathrm{ml}$ glass bottles, containing $40 \mathrm{ml}$ of filtered $(1.0 \mu \mathrm{m})$ and heated $\left(70^{\circ} \mathrm{C} ; 3 \mathrm{~h}\right)$ sea water at $23^{\circ} \mathrm{C}$ and $36 \%$. This gave a larval density of 5 larvae $\mathrm{ml}^{-1}$, similar to the densities used in commercial hatcheries. The bottles were aerated with an air bleed connected to an inline filter paper $(3 \mu \mathrm{m})$, and covered with aluminum foil to exclude dust and debris.

Comparative susceptibility assays. Before starting the susceptibility assays, the bacterial cultures were washed twice by centrifugation at $1431 \times g$ (Beckman GS-15 R centrifuge) with sterile (filtered and heated) saline solution $(2 \% \mathrm{NaCl})$, and resuspended in the same sterile saline solution to eliminate the TSB medium and bacterial metabolites. Preliminary experiments showed that TSB medium was toxic to the larvae. The $7 \mathrm{~d}$ old veliger larvae of the 4 lamellibranch species were challenged by inoculating APSA2 cells into the bottles to give initial concentrations of $0.1 \times$ $10^{5}, 0.5 \times 10^{5}, 2.5 \times 10^{5}, 5.0 \times 10^{5}$, and $10 \times 10^{5} \mathrm{cells} \mathrm{ml}^{-1}$. The larvae were fed daily with $3.0 \times 10^{4}$ cells ml ${ }^{-1}$ of Isochrysis galbana, which were free of thiosulfate citrate billiar salt sucrose (TCBS)-positive bacteria. Every $2 \mathrm{~d}$, half the water was changed to avoid accumulation of ammonia and other metabolites. Further inoculations of bacteria were not necessary, since in prelimi- 
nary experiments we found that exposing penshell larvae to the pathogen for $1 \mathrm{~d}$ was sufficient to produce the disease (Fig. 2).

One set of larvae with no bacterial additions served as controls. Each treatment was run in quadruplicate. Susceptibility was estimated by subtracting the moribund and dead larvae sinking to the bottom at different exposure times from the original number (200 larvae). Moribund larvae had closed valves, low ciliary activity and empty stomachs. Dead larvae showed no ciliary activity in the velum and gut, and had degraded tissues or empty valves. Signs of the disease were documented. With survival data, the median lethal concentration $\left(\mathrm{LC}_{50}\right)$ was calculated at different exposure times using the method of Rand \& Petrocelli (1985).

A 1-way analysis of variance (ANOVA) using the $F$ test was used to analyze the difference between treatments and controls. Values of $F<0.05$ were considered significantly different. Where significant differences were found, Tukey's HSD test was used to identify the nature of these differences $(\mathrm{p}<0.05)$.

\section{RESULTS}

The results of the assays on the $7 \mathrm{~d}$ old larvae of the 4 bivalve species at different Vibrio alginolyticus APSA2 concentrations (Fig. 3) show that survival in all lamellibranch species tested decreases when pathogenic bacteria concentration increases. However, important differences in susceptibility were seen among species. The most susceptible species at higher concentrations was the catarina scallop Argopecten ventricosus. Survival of its larvae was slightly affected at $0.1 \times 10^{5}$ cells ml $^{-1}$ during the $6 \mathrm{~d}$ of experimentation (Fig. 3b), but at concentrations of $0.5 \times 10^{5}$ cells ml $^{-1}$ survival decreased rapidly to $28 \%$ in just $3 \mathrm{~d}$ (Fig. $3 \mathrm{c}$ ), and at $2.5 \times 10^{5}$ cells ml $^{-1}$ nearly all the larvae were dead in the same period of time. Survival of larvae of the lion's paw scallop Nodipecten subnodosus was higher than for the catarina scallop at concentrations of $2.5 \times 10^{5}$ cells ml $^{-1}$ or lower $(\mathrm{p}<0.05)$, but at higher concentrations nearly all larvae were dead, similar to those of the catarina scallop $(\mathrm{p}<0.05)$. In contrast, during the first $4 \mathrm{~d}$ in all treatments, survival of penshell (Atrina maura) larvae remained above $60 \%$ and after this time survival decreased to $0 \%$ at concentrations above $2.5 \times 10^{5}$ on Day 6. Veligers of the Pacific oyster Crassostrea gigas were the most resistant larvae tested. Survival was near $40 \%$ in all treatments even on Day 6 (Fig. 3). Mortality occurred gradually in all treatments without the sudden mortality seen in typical epizootic events. Survival in the controls was similar in the 4 species $(\mathrm{p}<0.05)$, varying between $66 \%$ (A. maura) and $75 \%$ (C. gigas) on Day 6 (Fig. 3a).

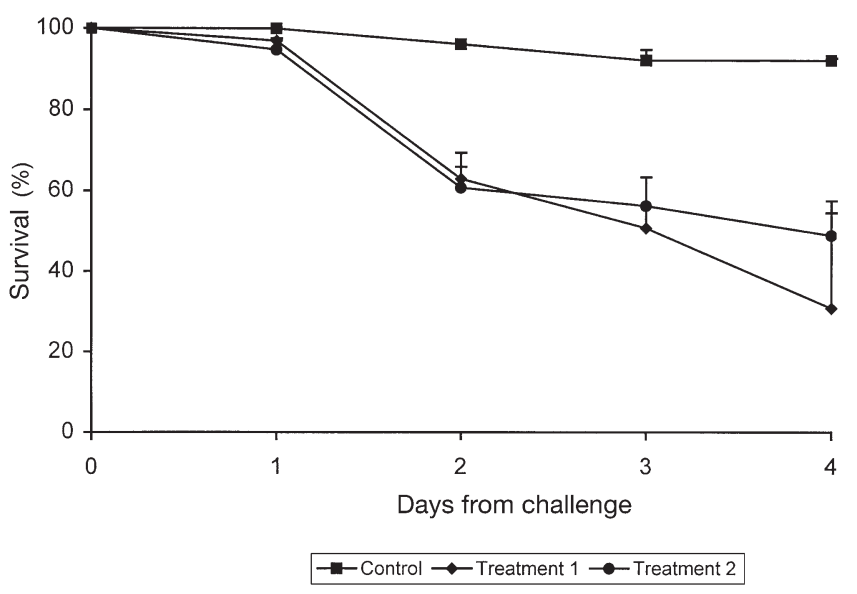

Fig. 2. Atrina maura. Preliminary experiment showing survival of $7 \mathrm{~d}$ old penshell veliger larvae challenged with $10 \times 10^{5}$ cells $\mathrm{ml}^{-1}$ of Vibrio alginolyticus APSA2 for $4 \mathrm{~d}$. In Treatment $1,50 \%$ of the water was changed every $48 \mathrm{~h}$, whereas in Treatment 2 complete water change was made $24 \mathrm{~h}$ from challenge. Values are means $( \pm \mathrm{SD})$ of 4 replicates. Significant differences were found between treatments and control, but not within treatments $\mathrm{p}<0.05$

From these results, the $\mathrm{LC}_{50}$ was calculated for each species at the different exposure times. The results (Table 1) show a higher susceptibility of the catarina (Argopecten ventricosus) and the lion's paw scallop (Nodipecten subnodosus) larvae to the pathogenic bacteria than the rest of the test species. On Day 1, the $\mathrm{LC}_{50}$ was $>10 \times 10^{5} \mathrm{cells} \mathrm{m}^{-1}$ for all species tested. However, on Day 2, $1.3 \times 10^{5}$ and $3.9 \times 10^{5}$ cells ml $^{-1}$ of Vibrio alginolyticus APSA2 were needed to kill half the $A$. ventricosus and $N$. subnodosus larvae, respectively, and $>10 \times 10^{5}$ cells ml $^{-1}$ to kill half of $A$. maura and Crassostrea gigas larvae. Similarly, on Day 4 , the $\mathrm{LC}_{50}$ was $0.3 \times 10^{5}$ and $1.5 \times 10^{5}$ cells ml ${ }^{-1}$ for $A$. ventricosus and N. subnodosus larvae, respectively, and $>10 \times 10^{5}$ cells ml ${ }^{-1}$ for A. maura and C. gigas larvae. On Days 5 and 6, a sudden decrease in $\mathrm{LC}_{50}$ was measured in penshell larvae, from $5.0 \times 10^{5}$ cells ml ${ }^{-1}$ on Day 5 to $0.8 \times 10^{5}$ cells ml ${ }^{-1}$ on Day 6 . The $\mathrm{LC}_{50}$ results

Table 1. Vibrio alginolyticus APSA2. $\mathrm{LC}_{50}\left(\right.$ cells ml $\left.{ }^{-1} \times 10^{5}\right)$ in $7 \mathrm{~d}$ old veliger larvae of 4 bivalve species, at different times from challenge. $>$ : concentrations not determined $\left(>10 \times 10^{5}\right.$ cells $\mathrm{ml}^{-1}$ )

\begin{tabular}{|lccccccc|}
\hline \multirow{2}{*}{ Species } & \multicolumn{8}{c|}{ Days from challenge } & \\
\cline { 2 - 7 } & 1 & 2 & 3 & 4 & 5 & 6 \\
\hline Argopecten ventricosus & $>$ & 1.3 & 0.3 & 0.3 & 0.2 & 0.1 \\
Nodipecten subnodosus & $>$ & 3.9 & 3.2 & 1.5 & 1.3 & 0.5 \\
Atrina maura & $>$ & $>$ & $>$ & $>$ & 5.0 & 0.8 \\
Crassostrea gigas & $>$ & $>$ & $>$ & $>$ & $>$ & 6.7 \\
& & & & & & & \\
\hline
\end{tabular}



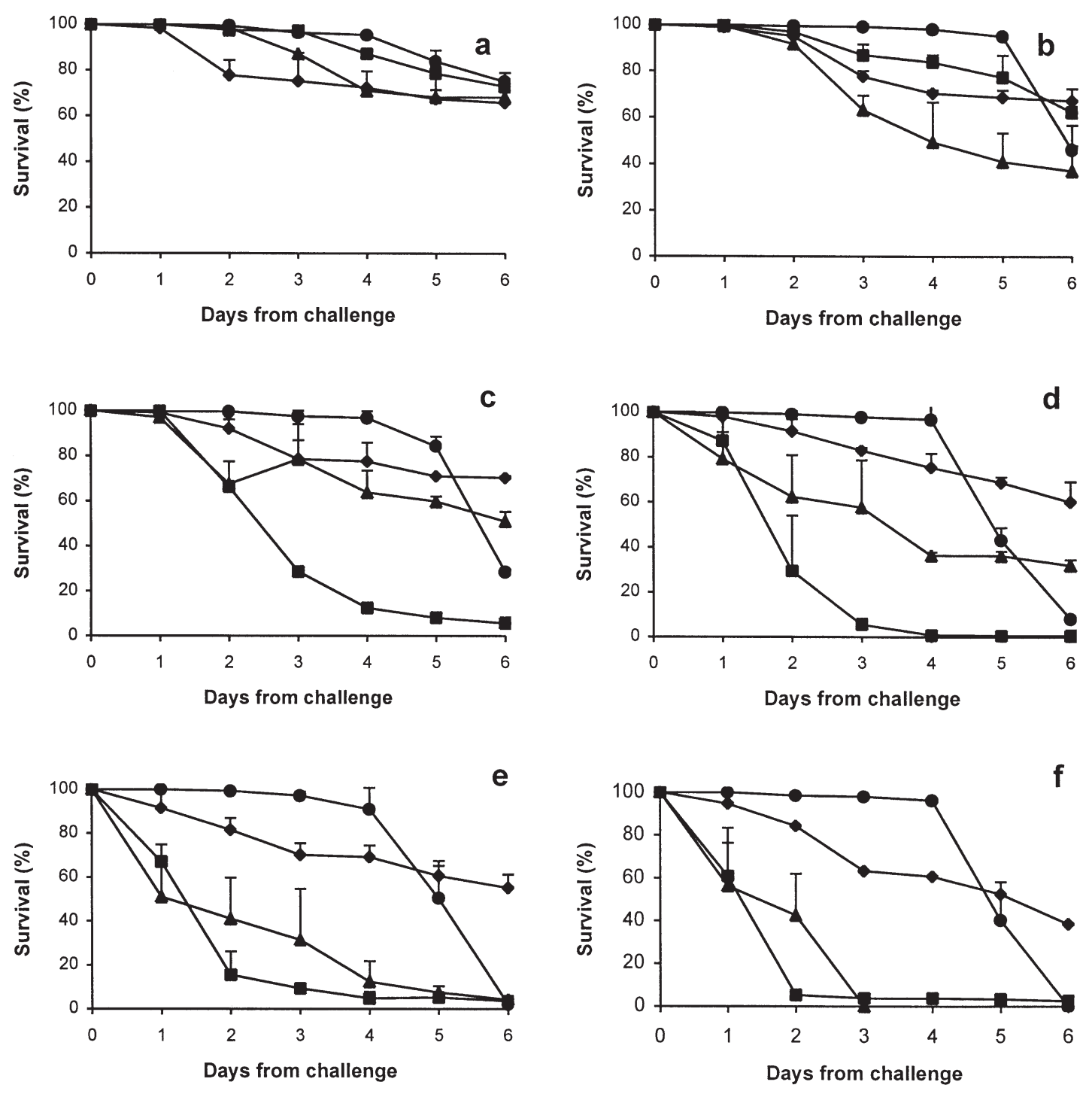

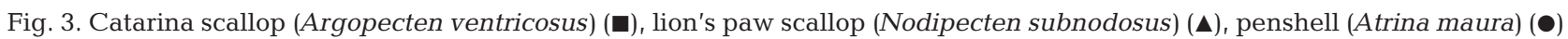
and Pacific oyster (Crassotrea gigas) ( $\bullet$ ). Survival of $7 \mathrm{~d}$ old veliger larvae challenged with Vibrio alginolyticus APSA2 at (a) 0 , (b) $0.1 \times 10^{5}$, (c) $0.5 \times 10^{5}$, (d) $2.5 \times 10^{5}$, (e) $5.0 \times 10^{5}$, and (f) $10 \times 10^{5}$ cells ml ${ }^{-1}$ over 6 d. Values are means $( \pm$ SD) of 4 replicates

for oyster (C. gigas) larvae showed that this species was the least susceptible to $V$. alginolyticus APSA2. Its $\mathrm{LC}_{50}$ remained at $>1000000$ cells $\mathrm{ml}^{-1}$ during the first $5 \mathrm{~d}$, and then declined to $6.7 \times 10^{5}$ cells $\mathrm{ml}^{-1}$ on Day 6.

The common signs of a bacillary necrosis disease (Tubiash et al. 1965) were observed in the larvae of the test species. Bacteria swarming around the velum, diminished swimming, generalized ciliar paralysis, empty stomachs, and necrotic tissues were common signs. Abnormal swimming in circular patterns and ciliar and velar detachment were seen in only a few larvae.

\section{DISCUSSION}

The results of the present work show important differences in susceptibility between lamellibranch larvae challenged with Vibrio alginolyticus APSA2. The larvae of the 2 scallop species tested were more susceptible to $V$. alginolyticus APSA2 than the penshell and the oyster, which supports our hypothesis of a higher susceptibility of scallop larvae to bacterial diseases. The same results were obtained by Tubiash et al. (1965), who challenged different lamellibranch larvae with the same ethiological agent. In their study, signs of disease were observed in all larval species 
tested in the first $5 \mathrm{~h}$ from seeding the vibrio. After $7 \mathrm{~h}$, $50 \%$ mortality was reported in Pecten maximus larvae, whereas in the rest of the species (Mercenaria mercenaria, Ostrea edulis, and Teredo navalis) mortality was $<25 \%$. These results confirm commercial scallop and oyster hatchery data, whereby oyster larvae appear to be less susceptible than scallop veligers. The high virulence of a strain producing vibriosis in just a few hours after seeding probably resulted from the high bacterial $\left(>10 \times 10^{5}\right.$ cells ml-1 ${ }^{-1}$ and larval $\left(25 \mathrm{ml}^{-1}\right)$ concentrations used by Tubiash et al.

There is still the question of why scallop larvae are more susceptible to Vibrio strains than other species. One approach is to examine the defense mechanisms of larvae and juveniles, as in the study of the defensive capabilities of disaggregated cells of Mytilus edulis larvae by Dyrynda et al. (1995) and the study of Mitta et al. (2000) on the syntesis of antimicrobial peptides in M. galloprovincialis. Mitta et al. reported that mytilin synthesis begins during larval metamorphosis and defensin syntesis ocurred when metamorphosis is complete. Differences in the defense systems of adult scallops and other bivalves are likely to exist. For example, the granular hemocytes which play a role in the defense system (Cheng 1981, Rodrick \& Ulrich 1984) of oysters and mussels are not present in the hemolymph of scallops (Auffret 1985).

The susceptibility of catarina scallop (Argopecten ventricosus) larvae to Vibrio alginolyticus APSA2 was higher than that recorded by Sainz et al. (1999) in similar experiments using larvae of the same species and age but challenged with a different strain of $V$. alginolyticus. In our experiments, the $\mathrm{LC}_{50}$ was $0.3 \times 10^{5}$ cells ml ${ }^{-1}$ on Day 4 (Table 1), against $6.5 \times 10^{5} \mathrm{cells} \mathrm{ml}^{-1}$ in Sainz's experiments over the same period of time. This could result either from strain-to-strain variations in virulence which have been reported elsewhere (Sugumar et al. 1998) or from variations in the quality of the larvae. Sugumar et al. found strain-to-strain variations in V. splendidus II on Pacific oyster larvae, with isolates from infected larvae being generally more virulent than those from other sources. Larval quality is difficult to assess, and this is usually inferred from survival rates during larval cultures. An example could be the differences in survival between penshell larvae (Atrina maura) challenged by $1 \times 10^{6} \mathrm{cells} \mathrm{ml}^{-1}$ of $V$. alginolyticus APSA2 bacteria in the preliminary assay of this work (Fig. 2) versus the assay shown in Fig. 3. Survival in the preliminary experiment dropped steadily down to a mean survival of $40 \%$ on Day 4 , whereas no appreciable mortality occurred in the same period of time during the later assay. The co-occurrence of undernourishment of the oocytes and suboptimal conditions such as temperature and salinity might have had a combined effect on the later assay, increas- ing the virulence of the pathogenic bacteria (Elston 1984).

Our work demonstrates the higher susceptibility of scallop larvae to pathogenic bacteria compared to other bivalve species. We believe that research work on the defense mechanisms of molluscan larvae in progress will confirm these findings. Susceptibility to bacterial diseases could be one of the most important criteria to define whether a certain species or group of species is suitable for spat production in a hatchery.

Acknowledgements. The present work was partially financed by Consejo Nacional de Ciencia y Tecnología, Mexico, project $1775 \mathrm{P}-\mathrm{B}$, and the internal project PAC5 at CIBNOR. Special thanks are given to Miguel Robles, María de Jesús Romero, Teodoro Reynoso, Pablo Monsalvo, and Pablo Ormart for technical support and the supply of test organisms. Our thanks to Dr. Ellis Glazier for editing the English of the manuscript.

\section{LITERATURE CITED}

Auffret M (1985) Morphologie comparative des types hémocytaires chez quelques Mollusques Bivalves d'intérêt commercial. PhD thesis, Université de Bretagne Occidentale, Brest

Brown C (1973) The effects of some selected bacteria on embryos of the American oyster, Crassostrea virginica. J Invertebr Pathol 21:215-223

Cheng TC (1981) Bivalves. In: Ratcliffe NA, Rowley AF (eds) Invertebrate blood cells, Vol 1. Academic Press, London, p 223-300

DiSalvo LH, Blecka J, Zebal R (1978) Vibrio anguillarum and larval mortality in a California coastal shellfish hatchery. Appl Environ Microbiol 35:219-221

Dyrynda EA, Pipe RK, Ratcliffe NA (1995) Host defense mechanisms in marine invertebrate larvae. Fish Shellfish Immunol 5:569-580

Elston R (1984) Prevention and management of infectious disease in intensive mollusc husbandry. J World Maricult Soc 15:284-300

Elston R, Leibovitz L (1980) Pathogenesis of experimental vibriosis in larval american oyster, Crassostrea virginica. Can J Fish Aquat Sci 37:964-978

Freites L, Lodeiros C, Vélez A, Bastardo J (1993) Vibriosis en larvas de la vieira tropical Euvola (Pecten) ziczac (L). Caribb J Sci 29:89-98

Garland CD, Nash GV, Summer CE, McMeekin TA (1983) Bacterial pathogens of oyster larvae (Crassostrea gigas) in a Tasmanian hatchery. Aust J Mar Freshw Res 34: $483-487$

Mitta G, Vandenbulcke F, Hubert F, Salzet M, Roch P (2000) Involvement of mytilins in mussel antimicrobial defense. J Biol Chem 275:12954-12962

Nicolas JL, Ansquer D, Cochard JC (1992) Isolation and characterization of a pathogenic bacterium specific to Manila clam Tapes philippinarum larvae. Dis Aquat Org 2: 153-159

Nicolas JL, Corre S, Gauthier G, Robert R, Ansquer D (1996) Bacterial problems associated with scallop Pecten maximus larval culture. Dis Aquat Org 27:67-76

Rand GM, Petrocelli SR (1985) Fundamentals of aquatic toxi- 
cology: methods and applications. Hemisphere Publishing Corporation, Washington, DC

Riquelme C, Hayashida G, Toranzo AE, Vilchis J, Chavez P (1995) Pathogenicity studies on a Vibrio anguillarumrelated (VAR) strain causing an epizootic in Argopecten purpuratus larvae cultured in Chile. Dis Aquat Org 22: 135-141

Rodrick GE, Ulrich SA (1984) Microscopical studies on the hemocytes of bivalves and their phagocytic interaction with selected bacteria. Helgol Wiss Meeresunters 37: $167-176$

Editorial responsibility: Albert Sparks,

Seattle, Washington, USA
Sainz JC, Maeda-Martinez AN, Ascencio F (1999) Experimental vibriosis induction with Vibrio alginolyticus of larvae of the catarina scallop (Argopecten ventricosus $=$ circularis) (Sowerby II, 1842). Microb Ecol 35:188-192

Sugumar G, Nakai T, Hirata Y, Matsubara D, Muroga K (1998) Vibrio splendidus biovar II as the causative agent of bacillary necrosis of Pacific oyster Crassostrea gigas larvae. Dis Aquat Org 33:111-118

Tubiash HS, Chanley PE, Leifson E (1965) Bacillary necrosis disease of larval and juvenile bivalve molluscs. 1. Etiology and epizootiology. J Bacteriol 90:1036-1044

Submitted: September 6, 2001; Accepted: November 9, 2001 Proofs received from author(s): May 21, 2002 